\title{
A tragédia grotesca no circo de Hermilo Borba Filho
}

\author{
Adriana Bertolucci Reis de Souza ${ }^{1}$
}

RESUMO: O presente artigo se propõe a analisar a obra do dramaturgo pernambucano Hermilo Borba Filho a partir da peça Electra no Circo (1944) e fazer uma ligação da tragédia grotesca desta com os conceitos propostos por Mikhail Bakhtin em “A cultura popular na Idade Média e no Renascimento O contexto de François Rabelais”.

ABSTRACT: The present paper aims at analyzing the work of Hermilo Borba Filho, a dramatist born at the state of Pernambuco, Brazil, through the play "Electra no Circo" (1944). We also attempt to make a link between its gortesque tragedy and the concepts proposed by Mikahin Bakhtin in "A cultura popular na Idade Média e no Renascimento - O contexto de Fraçois Rabelais”.

PALAVRAS-CHAVE: Hermilo Borba Filho; Teatro pernambucano; Tragédia Grotesca.

KEYWORDS: Hermilo Borba Filho; Theater from the state of Pernambuco; Grotesque tragedy.

O teatro brasileiro teve grandes conquistas no século XX com a busca de uma modernidade que quebraria os laços com as tradições portuguesas. No Sudeste, especificamente nas capitais Rio de Janeiro e São Paulo, essa nova linha de dramaturgia e encenação se destacou com a formação de novas companhias e com estreias de espetáculos como "O rei da vela" de Oswald de Andrade e "Vestido de noiva” de Nelson Rodrigues. Com a forte censura politica que as artes sofreram a partir dos anos 60, um dos grandes objetivos da dramaturgia foi buscar expressões da realidade social a partir do contato com o popular. A região Sudeste teve grandes momentos em que o povo foi personagem protagonista de enredos, como em "Eles não usam Black-Tie” de Gianfrancesco Guarnieri em 1958 e “Roda-viva”, dirigida

\footnotetext{
1 Aluna do Curso de Letras - UnB. Pesquisadora do Grupo: Literatura e Cultura - CAPES. Trabalho orientado pelo Prof. Dr. Augusto Rodrigues da Silva Junior (TEL/UnB). E-mail: dricaber@hotmail.com
} 
por Zé Celso em 1968. Mas foi no estado de Pernambuco, na região nordeste brasileira, que houve a grande representação da cultura popular no teatro nacional ${ }^{2}$.

O teatro pernambucano tinha como público alvo e também fonte de inspiração para criação o povo. E foi com a formação do Teatro do Estudante Pernambucano (TEP) em 1940 e em seguida com o Teatro Popular do Nordeste (TPN) na década de 60, que o movimento de forte ligação da dramaturgia com o popular se concretizou. E na formação dessas companhias, novos nomes surgiram na atuação nordestina e dramaturgos ganharam grande destaque. Dois autores que trabalharam na construção da dramaturgia nordestina foram Ariano Suassuna e Hermilo Borba Filho. Este último, ganhará no presente artigo, especial atenção por sua contribuição para o teatro brasileiro popular.

Hermilo Borba Filho escreveu textos de grande importância para a literatura moderna brasileira. Ajudou a construir e a disseminar a cultura do nordeste através de contos, novelas e peças teatrais. Dentre suas várias criações destacam-se obras literárias como:os textos para teatro Electra no Circo (1944) e A Barca de Ouro (1949); o romance Os caminhos da solidão (1957); a reunião de contos O general está pintando (1973) e a novela Os ambulantes de Deus (1976).

Borba Filho, além de escritor, literato e dramaturgo, foi um grande pesquisador da história do teatro. Fez profundos estudos sobre essa arte e também escreveu periodicamente críticas teatrais para colunas de jornais. Como concretização das suas pesquisas, Borba Filho publicou em 1968 "A história do espetáculo”, em que o autor faz uma viagem por toda a história do teatro ocidental. Suas obras, mesmo as novelas, sempre apontam para um tom de espetacularidade e dramaturgia. Percebe-se claramente referencias ao teatro popular nordestino: circo, fandangos e maracatus, como na obra “O general está pintando” (1973), onde personagens do povo vivenciam festas e atuações populares.

Articulando a dramaturgia grega com a reflexão cultural nordestina, Hermilo escreve em 1944 "Electra no Circo”, publicada na coletânea de 1952 juntamente com as obras João Sem Terra (1947) e A barca de ouro (1949). A constante ligação de Borba Filho com a cultura de sua terra nos faz lembrar a análise que Mikhail Bakht in

2 Ref.: MACIEL. Diógenes André V. Co mo e por que e eu leio a dramaturgia nordestina. In: GOMES, André L. Leio Teatro - dramaturgia brasileira contemporânea, leitura e publicação. São Paulo: Editora Horizonte, 2010. 
fez com a obra de Rabelais em A cultura popular na idade média e no renascimento o contexto de François Rabelais". Para o crítico russo, o autor francês se destacou na literatura mundial pois

sua principal qualidade é de estar ligado mais profunda e estreitamente que os outros [autores] às fontes populares, fontes específicas ( $\cdots)$; essas fontes determinaram o conjunto de seu sistema de imagens, assim como sua concepção artística. (BAKHTIN, 1996, P. 2).

Bakhtin denominou realismo grotesco como a herança modificada da cultura popular cômica. Nele, o princípio da vida material e corporal surge como forma universal, festiva e utópica em que há ligação indivisível do cósmico, do social e do corporal. O agente desse princípio é, então, o povo. Em Rabelais, há imagens do corpo, da bebida, da satisfação de necessidades naturais, da vida sexual, conservando a natureza original e diferenciando-se das imagens cotidianas. Ocorre uma nova junção das imagens clássicas que as trespassa, dando a elas um sentido dife rente. Para Bakhtin, é justamente a ligação da literatura com o caráter popular que fez a obra de Rabelais se diferenciar de toda a literatura ocidental do século XVI.

Maciel $^{3}$, diz que na obra de Borba Filho, a pesquisa estética da cultura nordestina implica em novas concepções harmônicas e auxiliam no trabalho de encenação das peças teatrais, na medida em que esses elementos de encenação se tornam presentes na dramaturgia da obra.

Em suas obras, Borba Filho, assim como Rabelais, faz constante ligação com a cultura popular, determinando seu conjunto artístico. De alguma maneira, é possível entender a obra de Borba Filho integrada à tradição rabelaisiana de representação do realismo grotesco. As manifestações culturais, como festas públicas e carnavalescas, compõem parcelas da cultura popular cômica, fazendo-se presente nas obras de ambos os autores.

Dessa maneira, a partir da ligação da obra de Rabelais e de Hermilo Borba Filho, pretende-se fazer uma análise da obra do autor nordestino a partir dos conceitos bakhtinianos publicados em 1996. Para isso, pretende-se analisar em

3 MACIEL, Diógenes. Como e por que eu leio a dramaturgia nordestina. In: Leio Teatro. dramaturgia brasileira contemporânea, leitura e publicação. São Paulo: Editora Horizonte, 2010. 
específico a peça Electra no Circo: compreender o drama inserido na realidade popular nordestina a partir da visão de Borba Filho.

Tal obra, assim como a Electra de Eurípedes (485 a.C - 406 a.C), trata de relações familiares conturbadas, temperadas de brigas, ciúmes, relações incestuosas, desejos de vingança e assassinatos. A peça se passa em dois planos diferentes que só são explícitos e, mais claramente distinguidos pelo leitor/ espectador ao final do texto.

Na obra de Eurípedes, sec. V a.C, 'Electra' narra a vingança final de Orestes, filho de Agamênon, rei de Micenas, contra os assassinos de seu pai. Electra é sua irmã e cúmplice do assassinato. Já na obra de Borba Filho, A Moça do Arame seria a personagem correspondente à Electra e seu pai era o Dono do Circo que foi morto por sua mãe, a Equitadora, para se casar com o Domador.. Na trama, o parceiro do assassinato da Moça do Arame é seu irmão: O Rapaz do trapézio e como cúmplice de toda a armação do picadeiro, há o Palhaço, figura carregada de tensão e densidade. Um dos pontos, portanto que difere a obra de Borba Filho com a de Eurípedes, é o ambiente em que o drama se passa: o circo. O cenário, um picadeiro, será palco das intrigas de família e disputa por poder da trupe. Borba Filho, portanto, apropria-se da temática grega e males que afligem o homem e os transporta para o cotidiano popular nordestino.

O primeiro ato, denominado de “Antes do espetáculo", é a apresentação da trama do circo, a explicação da morte do Dono do Circo. Além dos participantes do assassinato, Moça do Arame, Rapaz do trapézio e de cúmplice, o Palhaço, a trama conta com figuras constante como O Homem Lagarto e os coros tanto das Crianças que assistem o espetáculo do circo, quanto dos Serventes que trabalham para o mesmo.

O segundo ato, “Durante o Espetáculo”, é a concretização da tragédia encenada com a queda do Domador de cima de um trapézio. Além das cenas no picadeiro, um segundo plano surge no palco: o cenário é um sanatório e há um paciente que diz se chamar Orestes. As cenas dos dois planos se intercalam e, no terceiro ato "Depois do espetáculo" o paciente do sanatório tem algumas visões ou sonhos com a Moça do Arame, o Palhaço e o Dono do Circo e a trama vai então se 
concluindo com a união dos dois planos.

No palco circense, o popular encontra-se nas figuras como palhaços, trapezistas e em diálogos com o público. Logo na primeira fala do texto, um Mestre de Cerimônia apresenta o espetáculo com jargões de circo:

Mestre de Cerimônia: Respeitável público. Dentro de alguns minutos apresentaremos os números sensacionais do Grande Circo do Mundo. Não direi que haja feras. Não. Não direi isso. Vou até decepcionar a distinta plateia dizendo que não há feras. (BORBA FILHO, 2007, p.29)

Electra no Circo é uma representação de um cotidiano com características trágicas que se concentram em elementos que indicam a condição do indivíduo. O elemento fantástico aparece na obra para dar um diferente aspecto aos elementos locais. Neste caso, foi escolhido o ambiente circense como palco para inquietações pessoais e intrigas familiares. Assim como a disputa de poder dentro da instituição familiar, outra característica popular é a presença dos coros dos serventes e das crianças que acompanham durante toda a trama as ações dos personagens principais. Tal peça é, portanto a representação dos fatos comuns que ocorrem com pessoas simples em universos também simples.

O drama é formado com a voz de figuras que a princípio são cômicas, como por exemplo o palhaço. Porém, no decorrer do texto, se mostram inquietas e insatisfeitas com o contexto em que estão inseridas. O popular dessa vez não construirá o riso, como nas novelas posteriores de Borba Filho, mas sim, o drama. O Palhaço é um personagem de expressões grotescas e muito sentimental, e a Moça do Arame, uma menina revoltada com a situação de seus pais e com sede de vingança, reforçando o dialogo da peça com a Tragédia de Eurípedes. O realismo grotesco bakhtiniano é, para o próprio criador do termo, um sistema de imagens da cultura popular cômica. As imagens de realismo grotesco são "heranças da cultura cômica popular, de um tipo peculiar de imagem e, mais amplamente, de uma concepção estética da vida prática”(BAKHTIN, 1996, P.17).

Em espetáculos circenses cotidianos, comuns principalmente em cidades 
interioranas brasileiras, o palhaço faz o público rir pois está no palco disposto a qualquer situação que provoque o riso. É portanto, uma figura de refinados sentimentos. Entretanto, na obra de Borba Filho, é a partir da sutileza e sensibilidade que o dramático da obra se faz presente no palhaço e assim é apresentado ao público:

O Palhaço: E agora que jà viu tudo isso, veja o circo. O Grande Circo do Mundo. É um circo enorme, esse que você tanto desejava ver. E muito velho, também. Debaixo de sua coberta muitos dramas já foram representados, muitos homens já passaram. Todas as dores e todas as alegrias já desfilaram no picadeiro do Grande Circo do Mundo. (BORBA FILHO, 2007, p. 33).

A relação de figuras inseridas em uma suposta comédia popular e um drama dentro de personagens que, num contexto de espetáculo, se tornam carnavalizados, pode ser interpretada como “um corpo grotesco em formas carnavalescas”. Augusto Ponzio, em “A revolução bakhtiniana” (2010), diz que:

O corpo grotesco em suas formas carnvalescas [...] é uma metáfora válida, que podemos utilizar para compreender o contraste entre duas visões de mundo em uma mesma cultura. Por um lado, Bakhtin concebe o corpo como individual e fechado, auto-suficiente e isento de qualquer relação com outros corpos; por outro lado o coloca em uma relação intercorporal. Trata-se de um corpo aberto, com protuberâncias e furo, visto em todos os comportamentos que inevitavelmente o relacionam com o exterior. Encontramos assim o fechamento para a identidade e a abertura para a alteridade (PONZIO, 2010, p. 25).

Além da figura do Palhaço, também chamam a atenção as imagens das Crianças Pobres, espectadoras do circo que acompanham toda a trama. Essas figuras nos fazem perceber a miscigenação da pureza das crianças com o drama de incestos, 
assassinatos e loucura. É também em cima dessas crianças que Borba Filho faz a crítica social dentro do contexto literário.

A concretização do popular em situações de disputas familiares, situações cotidianas circenses como a abertura do espetáculo com a fala de um Mestre de Cerimônia, perguntas e respostas comuns em circos, fazem o público se lembrar e fazer referências a uma cultura que já são inseridos, em imagens e principalmente em diálogos.

Palhaço: Hoje tem espetáculo?

Os serventes: (Levantam a cabeça como se ouvissem um chamado) - Tem, sim senhor. (BORBA FILHO, 2007, p.32).

No plano fantástico, personagens reais, com toques de carnavalização narram a história de vingança e incesto. A antiga narrativa de Electra é recontada por Borba Filho nos moldes populares nordestinos, dentro de um contexto circense. A filha, representada pela personagem de uma Moça do Arame, planeja o assassinato da mãe e do seu marido durante uma das apresentações. Borba Filho propõe a encenação. O fatal se concretiza com uma queda do corpo do Domador do alto de um trapézio: um barulho quase ensurdecedor. Crianças sentem o medo mais puro de uma infância assustadora enquanto o palhaço assiste a tudo como cúmplice do assassinato.

Podemos dizer que todas essas imagens citadas acima, são figuras retiradas do cotidiano popular e transformadas em realidades grotescas. Esses personagens são caricaturas do povo, como o medo das crianças, o susto do palhaço, a filha que disputa o poder dentro da família, construindo o drama. O assassinato dentro de um circo é a representação de crises pessoais onde se questiona o poder dentro de uma instituição e a vida como espetáculo, transportados para a teatralidade. "A base deste Teatro Popular é sempre uma referência aristotélica. Mas os personagens “imitados” não são seres superiores, são pessoas comuns.” (SILVA JR., 2000). A morte programada seria a concretização do grande desejo de degradação do corpo. Entretanto, tal comunhão com a terra não se faz da mesma maneira que Rabelais fazia, de acordo com Bakhtin. Para esse, na obra daquele 
Degradar significa entrar em comunhão com a vida da parte inferior do corpo, a do ventre e dos órgãos genitais, e portanto com atos com o coito, a concepção, a gravidez, o parto, a absorção de alimentação e a satisfação de necessidades naturais (BAKHTIN, 1996, p.19)

A construção do drama nesta obra de Borba Filho, é feita, então, com figuras que não apresentam caráter egoísta e pessoal, mas sim, como o próprio Bakhtin explica em relação a personagens representativos de um povo (como Sancho Pança), um utopismo popular. Pois na abertura tanto do segundo ato quanto do terceiro, o Mestre de Cerimônia diz que os atores do Grande Circo do Mundo estavam fazendo toda aquela encenação porque queria viver a própria vida, e não mais a de personagens. E tal reflexão é comum em todo ambiente de atuação pois não se tem uma resposta sobre quando há a linha divisória do ator com o homem.

A concretização da morte para a Moça do Arame e para o Rapaz do Trapézio “cava o túmulo corporal para dar lugar a um novo nascimento” (BAKHTIN, 1996, P.19). É somente dessa maneira que Electra se satisfaz por completo: ligando o corpo do outro com a terra, rebaixando-o para entrar em contato com esta. Essa satisfação do desejo de morte de outro corpo é um reinício da sua própria vida: “O realismo grotesco não conhece outro baixo; o baixo é a terra que dá vida, e o seio corporal; o baixo é sempre o começo” (BAKHTIN, 1996, p.19);

A existência de dois planos na obra de Borba Filho, permite duas leituras: uma que representa a realidade cultural local dentro de um meio fantástico, e outra que demonstra problemas intimistas e psicológicos. No plano da realidade, como o próprio Borba Filho cita em seu texto, há “personagens reais”, e as cenas se passam em um sanatório, com ar de naturalidade. O paciente número treze, responsável pelas visões e sonhos do plano fantástico, cita suas alucinações com os doutores, confunde sua história com a história grega de Electra e confunde sua personalidade com a de Orestes, irmão de Electra. Confusões mentais preenchem o terceiro ato da peça, intitulado pelo autor de “Depois do espetáculo”.

O trauma que sofre o paciente do sanatório se aproxima da tragédia clássica e portanto o surgimento do nome da peça. Os personagens reais se assustam com a 
situação de um filho que matou a mãe e que demonstra atitudes de insanidade. É discutida a linha que separa a sanidade da razão, e a distinção de um ponto à outro é de difícil acesso. Seria o paciente um louco ou um criminoso? É, então, dessa maneira que Borba Filho se aproxima ao máximo da realidade intimista do ser humano. Problemas pessoais discutidos desde a Grécia são mais uma vez repensados na obra do dramaturgo pernambucano.

O plano da realidade faz conexão com o da fantasia com a participação da voz do paciente nas ações dos personagens circenses. Somente quem escuta e dialoga com essa voz é o próprio “Rapaz do trapézio”, personagem que faz referência a Orestes de Eurípedes. Essa voz é a consciência da figura real que interfere constantemente nas figuras fantásticas, tanto esclarecendo, quanto confundindo. No decorrer do texto percebe-se que todo o ambiente circense é um sonho, e que essa voz que aparece para intrigar ou questionar é a voz do próprio sonhador.

Esse texto de Borba Filho se torna instigante pois de maneira inteligente o autor constrói a encenação de um sonho que abraça uma realidade.

\begin{abstract}
Abre-se o pano de boca. Dois palcos superpostos. Ambos estão com as cortinas cerradas. No de cima, que é uma sala de sanatório, movimentam-se os personagens reais. No de baixo, uma rotunda escura que é o cérebro do Rapaz do Trapézio, tem um lugar as cenas imaginadas pela sua loucura. Abre-se a cortina do palco superior. $O$ Primeiro Médico está sentado escrevendo. Entra o Segundo Médico.( BORBA FILHO, 2007, p.61)
\end{abstract}

O drama acontece, no plano fantástico, porque artistas do circo resolvem viver a própria vida, viver a própria tragédia. O espetáculo se torna para aqueles que atuam nas concretizações dos seus desejos, como a Moça do Arame e o Rapaz do Trapézio, uma grande celebração. Porque era somente dessa maneira que ambos poderiam continuar vivendo, continuar evoluindo. Era preciso vingança. Os corpos da Moça do Arame e do Rapaz do Trapézio são então, imagens grotescas, pois “caracteriza um fenômeno em estado de transformação, de metamorfose e ainda 
incompleta, no estágio da morte e do nascimento, do crescimento e da evolução" (BAKHTIN, 1996, p.21 ). Esses dois personagens necessitavam da concretização da vingança da morte do pai para uma evolução. Afinal, como o próprio Bakhtin cita, a atitude em relação à evolução é um traço determinante e indispensável da imagem grotesca.

Electra no Circo é uma obra com elementos atuais. Trabalha com temas atemporais, como a questão do incesto, tramas familiares, justiça e vingança, e também constrói o popular de seu tempo e principalmente de sua localidade. Crianças e palhaços se assustam, o espetáculo do circo faz chorar. A justiça é feita com mais um pecado, uma morte é equilibrada com mais outras duas. O justo é repensado na questão em que homens, em condições mínimas, são reféns de um destino opressor. Até que ponto o ator atua ou vive seus desejos, suas próprias expressões e seu corpo? Não se pode dizer que Electra no Circo é uma obra literária fantástica. Há sim elementos fantásticos, mas estes são figuras que se inserem em uma realidade social. No plano da memória, tanto no primeiro quanto no segundo ato, os diálogos são permeado de vozes que interferem nas ações e e que dialogam entre si em um ambiente à parte da ação do picadeiro. Essas vozes são vozes de personagens que já morreram no enredo, ou vozes de personagens que estão em cena no mesmo momento que aparecem para o público. Cria-se então ilusões e dúvidas em relação à origem e procedência dessas vozes. Ao mesmo tempo, elas são de extrema importância para a discussão dos personagens, quando estas interferem nas ações deles. No terceiro ato, a presença fantástica se faz com a aparição das Mulheres de Preto: senhoras que assistem da plateia do crico toda a vingança dos filhos e os julgam posteriormente. E assim como essas senhoras, também surgem no plano da memória Homens de Branco e um Juíz. Todos como agentes do julgamento do Rapaz do Trapézio. São figuras carregadas de elementos imagéticos e simbólicos e que fazem parte da realidade de qualquer sociedade.

O Mestre de Cerimônia, figura que está a par de todos os ocorrentes no plano fantástico mas não interfere em nenhuma ação, fala durante a abertura do segundo ato (Durante o Espetáculo), que ele havia ficado surpreso com a reação dos artistas que "estavam mostrando um pedaço de suas vidas, um drama doméstico que 
nada tinha a ver com a condição de artistas”. Em um suposto diálogo deste personagem com os outros artistas do circo, esses disseram que “já estavam cansados de sua condição de fantoches, que queriam viver a sua própria história”. O questionamento é feito, então: o artista deve viver em cena? E na festa? Quem é que vive no carnaval? Quem são aqueles foliões que transformam seus desejos em realidades?

Para Bakhtin, é a vida que atua e representa no carnaval e por um determinado tempo, esse jogo se transforma em vida real. Essa festa então é a segunda vida do povo. Pois a verdadeira celebração humana, e aqui podemos dizer que a vingança dos irmãos pela morte do pai foi um momento de celebração, um momento quase (e não puramente) carnavalesco, pois idolatra a instabilidade, a mutabilidade e a não obediência de valores hierárquicos, políticos e morais. E além disso, trabalha com dúvida da separação entre homem- ator.

Borba Filho portanto foi completo em sua obra. Discutiu questões sociais mas principalmente, retratou de maneira extraordinária os sentimentos de seu povo. E com uma forma brilhante de dramaturgia, conseguiu dialogar o popular nordestino com a tragédia grega. Em tempos de crise política e busca por um povo vivo na dramaturgia brasileira, Borba Filho brilhou com seu texto e sua obra. Sem deixar de lado a estética e a encenação, o pesquisador e o dramaturgo se fizeram presentes e criaram e juntos em uma só obra o povo, o circo, a vingança e o desejo humano.

\section{REFERÊNCIAS BIBLIOGRÁFICAS}

ALVES, Leda, REIS, Luís Augusto, organizadores. Hermilo Borba Filho: teatro selecionado. Rio de Janeiro: Funart, 2007.

BAKHTIN, Mikhail. A cultura popular na idade média e no renascimento. O contexto de François Rabelais. Ed. Universidade de Brasília, 1996. São Paulo- Brasília.

BORBA FILHO, Hermilo. Electra no Circo [1944]. In: Teatro. Recife: Edições TEP, 1952.

. Electra no Circo [1944]. In: Teatro. Recife: Edições TEP, 1952.

. João Sem Terra [1947]. In: Teatro. Recife: Edições TEP, 1952. 
. A Barca de Ouro [1949]. In: Teatro. Recife: Edições TEP, 1952.

O general está pintando. Ed. Globo, 1973, Porto Alegre.

. História do espetáculo. Rio de Janeiro: Edições O Cruzeiro, 1968.

GOMES, André Luís; MACIEL, Diógenes André Vieira [Orgs.] Dramaturgia e teatro: intersecções. Maceió: UFAL, 2008.

MACIEL. Diógenes André V. Como e por que e eu leio a dramaturgia nordestina. In: GOMES, André L. Leio Teatro - dramaturgia brasileira contemporânea, leitura e publicação. São Paulo: Editora Horizonte, 2010.

PONZIO, Augusto. A revolução bakhtiniana. São Paulo: Editora Contexto, 2010.

SILVA JR. Augusto R. Bakhtin: Leitor de Romances. In: Conversas Escritas para o Círculo 2009.

Disponível

em:

〈http://conversasbakhtinianas.blogspot.com/search/label/Augus to\%20Rodrigues $>$.

Acesso em: 30 ago. 2010.

SILVA JR. Augusto R. Os ambulantes de Deus: a morte, a memória e a travessia do tempo. UFPE, 2000. (Apresentação de Trabalho/Comunicação).

Os ambulantes de Deus e a travessia dos gêneros em Hermilo Borba Filho. ANPOLL - GT Dramaturgia e Teatro. Encontro intermediário, UFPB, João Pessoa, 2009. (Apresentação de Trabalho/Comunicação). 